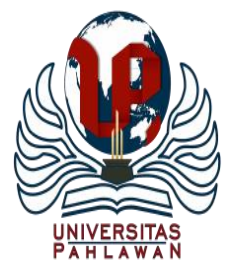

Edukatif : Jurnal Ilmu Pendidikan Volume 3 Nomor 4 Tahun 2021 Halm 1231 - 1244

EDUKATIF: JURNAL ILMU PENDIDIKAN

Research \& Learning in Education

https:/ledukatif.org/index.php/edukatif/index

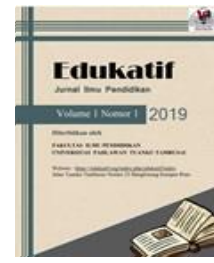

\title{
Pengembangan Sistem Pembelajaran Flipped Classroom Berbasis Inkuiri Terbimbing pada Materi Hidrolisis Garam
}

\section{Zarnida Widia Nengsih ${ }^{1 凶}$, Mawardi Mawardi ${ }^{2}$}

Universitas Negeri Padang, Indonesia ${ }^{1,2}$

E-mail : zarnidawidianingsih@gmail.com ${ }^{1}$, mawardianwar@fmipa.unp.ac.id ${ }^{2}$

\begin{abstract}
Abstrak
Akibat terjadinya pandemi covid-19, kegiatan belajar dilakukan secara daring atau online. Selain itu, kurikulum 2013 menuntut pembelajaran yang berpusat pada peserta didik. Oleh karena itu, perlu dilakukan penelitian yang bertujuan untuk mengembangkan sistem pembelajaran flipped classroom berbasis inkuiri terbimbing pada materi Hidrolisis Garam dan menguji kevalidan serta kepraktisan sistem pembelajaran yang dihasilkan. Jenis penelitian adalah Research and Development (R\&D) dengan tahapan model Plomp, yaitu: (1) preliminary research, (2) development or prototyping phase, dan (3) assessment phase (tidak dilakukan). Data hasil penelitian dari angket validasi dianalisis dengan menggunakan rumus Aiken's $V$, sedangkan data angket praktikalitas dianalisis dengan cara persentase. Berdasarkan hasil penelitian, sistem pembelajaran yang dikembangkan telah valid baik dari segi materi maupun media serta sistem pembelajaran sangat praktis dalam penggunaannya. Oleh karena itu, sistem pembelajaran ini dapat digunakan sebagai salah satu alternatif pelaksanaan pembelajaran secara daring.
\end{abstract}

Kata Kunci: Flipped Classroom, Hidrolisis Garam, Inkuiri Terbimbing.

\begin{abstract}
As a result of the covid-19 pandemic, learning activities were carried out. In addition, the 2013 curriculum demands student-centered learning. Therefore, it is necessary to conduct research aimed at developing a learning system based on guided inquiry flipped classroom on Salt Hydrolysis material and testing the validity and practicality of the resulting learning system. The type of research is Research and Development $(R \& D)$ with the Plomp model stages, namely: (1) preliminary research, (2) development or prototyping phase, and (3) assessment phase (not carried out). The research data from the validation questionnaire were analyzed using the Aiken's $V$ formula, while the practicality questionnaire data were analyzed by means of a percentage. Based on the research results, the learning system developed has been valid both in terms of material and media and the learning system is very practical in its use. Therefore, this learning system can be used as an alternative for implementing online learning.
\end{abstract}

Keywords: Flipped Classroom, Salt Hydrolysis, Guided Inquiry.

Copyright (c) 2021 Zarnida Widia Nengsih, Mawardi Mawardi

$\triangle$ Corresponding author

Email : zarnidawidianingsih@gmail.com

DOI : https://doi.org/10.31004/edukatif.v3i4.546

ISSN 2656-8063 (Media Cetak)

ISSN 2656-8071 (Media Online)

Edukatif : Jurnal Ilmu Pendidikan Vol 3 No 4 Tahun 2021 p-ISSN 2656-8063 e-ISSN 2656-8071 
1232 Pengembangan Sistem Pembelajaran Flipped Classroom Berbasis Inkuiri Terbimbing pada Materi Hidrolisis Garam - Zarnida Widia Nengsih, Mawardi Mawardi

DOI: https://doi.org/10.31004/edukatif.v3i4.546

\section{PENDAHULUAN}

Virus corona merupakan jenis virus yang mulai berkembang pada awal tahun 2020. Virus tersebut berasal dari Wuhan, satu kota di China, dan ditemukan pada akhir Desember 2019. Organisasi Kesehatan Dunia, WHO (World Health Organization) menamai virus itu dengan nama SARS-CoV-2 sedangkan penyakit yang diakibatkan oleh virus ini dinamakan Corona Virus Disease 2019 (COVID-19) (He et al., 2020). Seiring berjalannya waktu, wabah virus corona merebak di Indonesia. Keadaan ini menyebabkan terganggunya tatanan kehidupan di semua bidang termasuk dunia pendidikan. Untuk mengurangi resiko penularan dan penyebaran virus corona di Indonesia, pemerintah mengeluarkan peraturan yang menginstruksikan pelaksanaan kegiatan belajar dilakukan secara daring atau jarak jauh (Mendikbud, 2020). Penerapan pembelajaran daring dapat mengakibatkan kegiatan belajaran tidak terlaksana secara optimal seperti pada pembelajaran tatap muka. Menurut (Fauzy \& Nurfauziah, 2021), kendala yang terjadi dalam pelaksanaan pembelajaran daring disebabkan karena kesulitan peserta didik dalam beradaptasi dengan keadaan pembelajaran tersebut serta guru yang belum siap dalam melaksanakan pembelajaran secara tiba-tiba (Fauzy \& Nurfauziah, 2021). Selain itu, kejenuhan yang dirasakan oleh peserta didik akibat tidak adanya interaksi bersama teman-temannya menyebabkan peserta didik kesulitan dalam memahami materi pembelajaran (Kartika et al., 2021).

Blended learning dapat menjadi salah satu strategi pelaksanaan pembelajaran jarak jauh selama masa pandemi covid-19. Pembelajaran blended learning menggabungkan dua strategi pembelajaran, yaitu kegiatan belajar dilakukan pada tempat yang berbeda dengan waktu tidak terbatas atau dikenal dengan asynchronous dan pembelajaran tatap muka yang dikenal dengan istilah pembelajaran synchronous. Blended learning terdiri atas banyak model. Salah satu bagian dari blended learning adalah flipped classroom (Watson et al., 2015). Pembelajaran flipped classroom atau pembelajaran dengan kelas terbalik ini membalikkan pembelajaran tradisional yang terbagi atas pembelajaran di kelas dan pembelajaran setelah kelas (belajar di rumah) (Syakdiyah et al., 2020). Sedangkan pembelajaran dengan sistem pembelajaran flipped classroom dilakukan dalam dua fase, yaitu fase diluar kelas (asynchronous) dan fase di dalam kelas (synchronous) (Aumi \& Mawardi, 2021), (Waer \& Mawardi, 2021). Menurut (Mirlanda et al., 2019), sistem pembelajaran flipped classroom dapat meningkatkan kemandirian peserta didik dalam kegiatan belajar(Mirlanda et al., 2019) dan meningkatkan motivasi serta hasil belajar (Widyasari \& Rafsanjani, 2021). Selain itu, pembelajaran flipped classroom dapat meningkatkan umpan balik dalam pembelajaran (Goedhart et al., 2019).

Pembelajaran asynchronous yang dilakukan secara jarak jauh atau daring membutuhkan suatu LMS (Learning Menagement System) dalam pelaksanaannya. Learning Menagement System atau LMS merupakan suatu sistem yang digunakan untuk mengatur dan mengontrol pelaksanaan pembelajaran online atau daring (Fitriani, 2020). Salah satu LMS yang dapat digunakan adalah Edmodo. Menurut Purnawarman et al. (2016), penggunaan Edmodo dalam pembelajaran daring dapat membuat peserta didik terlibat langsung dan aktif dalam kegiatan belajar (Purnawarman et al., 2016). Selain itu, peserta didik akan mengalami peningkatan kemampuan dalam menganalisis materi pembelajarannya (Wahyuni et al., 2019). Selanjutnya, pembelajaran tatap muka atau synchronous dapat dilakukan secara tatap maya atau dikenal juga dengan synchronous online (Jung \& Brady, 2020). Hal ini sesuai dengan aturan yang dikeluarkan oleh pemerintah bahwa pembelajaran tatap muka diganti dengan pembelajaran secara daring. Menurut (Kohnke \& Moorhouse, 2020), salah satu aplikasi yang dapat mendukung pelaksanaan pembelajaran tatap maya adalah aplikasi Zoom(Kohnke \& Moorhouse, 2020). Melalui aplikasi Zoom, guru dan peserta didik dapat berinteraksi secara virtual pada waktu yang sama walaupun di tempat yang berbeda-beda (Simamora, 2020).

Penggunaaan Teknologi Informasi dan Komunikasi (TIK) seperti Edmodo dan Zoom dalam proses pembelajaran merupakan salah satu upaya adaptasi pada era revolusi industri 4.0. Era revolusi industri 4.0 merupakan masa dimana teknologi memiliki peranan penting dalam semua bidang kehidupan termasuk bidang 
1233 Pengembangan Sistem Pembelajaran Flipped Classroom Berbasis Inkuiri Terbimbing pada Materi Hidrolisis Garam - Zarnida Widia Nengsih, Mawardi Mawardi

DOI: https://doi.org/10.31004/edukatif.v3i4.546

pendidikan. Menurut Yuliati \& Saputra (2019), peserta didik diharapkan mampu menerapkan kemampuannya dalam penggunaan teknologi untuk mendukung pelaksanaaan kegiatan belajarnya terutama pada saat pembelajar daring atau pembelajaran online ini(Yuliati \& Saputra, 2019).

Selain pelaksanaan pembelajaran secara online, kegiatan pembelajaran yang dilakukan juga harus memenuhi tuntutan dari kurikulum 2013. Kurikulum 2013 menuntut pembelajaran yang berpusat pada peserta didik. Selain itu, peserta didik diharapkan mampu berpikir secara kritis. Oleh karena itu, pembelajaran harus dilakukan dengan menerapkan model pembelajaran saintifik, salah satunya yaitu model inkuiri terbimbing. Menurut (Hanson, 2005), tahapan pembelajaran inkuiri terbimbing terdiri atas: (1) orientasi, (2) eksplorasi, (3) pembentukan konsep, (4) aplikasi, dan (5) penutup (Hanson, 2005). Pembelajaran inkuiri terbimbing dapat memenuhi tuntutan Kurikulum 2013 agar peserta didik dapat terlibat aktif dan interaktif dalam kegiatan belajar (Mawardi \& Asra, 2011).

(Fautch, 2013) melakukan penelitian tentang "The flipped classroom for teaching organic chemistry in small classes: is it effective?". Berdasarkan penelitian tersebut dapat disimpulkan bahwa pembelajaran flipped classroom menggunakan kelas kecil pada kimia organik efektif penggunaannnya. Hal ini ditunjukkan dengan peningkatan pemahaman materi dan peningkatan kinerja peserta didik pada saat ujian. Peserta didik menunjukkan respon bahwa pembelajaran menjadi lebih nyaman dan menarik dengan cara flipped classroom ini(Fautch, 2013).

Kemudian, (Syakdiyah et al., 2020) melakukan penelitian mengenai "Flipped Classroom Learning Inovation as an Attempt to Strengthen Competence and Competitiveness of Students in the 4.0 Industrial Revolution Era " dengan kesimpulan bahwa flipped classroom dengan segala bentuk modifikasi dapat mengikuti era industri 4.0. Pembelajaran menggunakan strategi flipped classroom dapat membuat peserta didik mengeksplorasi kemampuannya, mandiri, dan bertanggung jawab sehingga hasil belajar peserta didik dapat meningkat(Syakdiyah et al., 2020).

Selanjutnya, (Mawardi \& Asra, 2013) melakukan penelitian tentang "Inkuiri Terbimbing Sebagai Salah Satu Strategi Pembelajaran Kimia untuk Memenuhi Tuntutan Kurikulum 2013" dan didapat disimpulkan pembelajaran inkuiri terbimbing dapat memenuhi tuntutan Kurikulum 2013 agar peserta didik dapat terlibat aktif dan interaktif dalam kegiatan belajar (Mawardi \& Asra, 2013).

Kemudian, (Béres \& Kis, 2018) melakukan penelitian mengenai "Flipped Classroom Method Combined with Project Based Group Work" dapat didapat kesimpulan terjadi peningkatan tanggung jawab peserta didik dalam kegiatan belajar melalui penggabungan metode flipped classroom dengan kerja kelompok berbasis proyek. Pendidik meminta peserta didik untuk mempelajari materi sebelum kegiatan kelas. Hal ini membuat peserta didik harus berperan aktif dalam kegiatannya pembelajaran sendiri (Béres \& Kis, 2018).

Berdasarkan uraian di atas, maka perlu dilakukan penelitian yang bertujuan untuk menghasilkan sistem pembelajaran flipped classroom berbasis inkuiri terbimbing. Penelitian ini memiliki perbedaan dari penelitian sebelumnya. Penelitian sebelumnya (Syakdiyah et al., 2020) hanya melihat efektivitas pelaksanaan flipped classroom tanpa penggunaaan model pembelajaran saintifik dalam pelaksanaannya. Sedangkan pelaksanaan pembelajaran harus menggunakan salah satu model pembelajaran saintifik sesuai tuntutan kurikulum 2013, salah satunya adalah model inkuiri terbimbing seperti pada penelitian (Mawardi \& Asra, 2013). Namun, pelaksaan model inkuiri terbimbing belum dapat memenuhi tuntutan kurikulum 2013 seperti pada penelitian oleh (Mawardi \& Asra, 2013) ketika pelaksanaan pembelajaran daring selama masa pandemi Covid-19. Hal ini sesuai dengan hasil pengamatan peneliti di sekolah dimana pembelajaran yang terjadi hanya berpusat pada guru bukan berpusat pada peserta didik. Pada penelitian (Béres \& Kis, 2018), metode flipped classroom digabungkan dengan kerja kelompok berbasis proyek menyebabkan peserta didik menjadi aktif. Namun, pembelajaran kombinasi ini tidak cocok dilakukan pada pembelajaran daring karena peserta didik tidak bisa mengerjakan proyek secara berkelompok pada masa pandemi Covid-19. Pada saat ini belum ditemukan kombinasi metode flipped classroom dengan model inkuiri terbimbing. Peneliti berharap, sistem pembelajaran 
1234 Pengembangan Sistem Pembelajaran Flipped Classroom Berbasis Inkuiri Terbimbing pada Materi Hidrolisis Garam - Zarnida Widia Nengsih, Mawardi Mawardi

DOI: https://doi.org/10.31004/edukatif.v3i4.546

flipped classroom berbasis inkuiri terbimbing yang dikembangkan dapat mempermudah pelaksanaan pembelajaran secara daring dan tetap terlaksannya pembelajaran yang berpusat pada peserta didik. Untuk melihat penerapan sistem pembelajaran ini, maka perlu diterapkan pada salah satu materi kimia yaitu Hidrolisis Garam yang diajarkan pada kelas XI SMA/MA.

\section{METODE}

Objek penelitian yang berupa sistem pembelajaran flipped classroom berbasis inkuiri terbimbing pada materi Hidrolisis Garam untuk kelas XI SMA/MA akan dinilai dengan menggunakan instrumen penelitian berupa angket validitas dan angket praktikalitas. Instrumen tersebut akan diberikan kepada dosen Jurusan Kimia FMIPA UNP, dosen Teknik Elektonika FT UNP, guru kimia di SMA Negeri 1 Ranah Pesisir, dan peserta didik SMA Negeri 1 Ranah Pesisir khususnya kelas XI IPA sesuai dengan proporsinya masingmasing.

Penelitian di FMIPA UNP dan SMA N 1 Ranah Pesisir dilakukan sesuai dengan tahapan pengembangan model Plomp (Plomp, 2013). Tahap yang pertama adalah preliminary research (tahap penelitian awal). Pada tahap ini, dilakukan analisis kebutuhan dan analisis konsep terhadap masalah penelitian yang akan dilakukan. Selanjutnya, dilakukan kegiatan studi literatur mencari teori-teori sehingga ditemukan solusi dari masalah yang akan diteliti. Setelah ditemukan solusi dari masalah telah ditemukan, maka dilakukan kegiatan pengembangan kerangka konseptual, yaitu mengembangkan kerangka produk yang dikembangkan serta mengembangkan konsep-konsep yaang dipelajari pada materi Hidrolisis Garam.

Tahapan yang kedua yaitu development or prototyping phase (tahap pembuatan prototipe). Pada tahap pembuatan prototipe ini dilakukan evaluasi formatif untuk menyempurnakan produk yang telah dikembangkan. Produk hasil rancangan pertama dinamakan dengan prototipe I. Evaluasi formatif yang dilakukan pada prototipe I adalah self evaluation dengan sistem check list. Evaluasi ini dilakukan oleh peneliti untuk melihat komponen-kompen yang harus ada pada sistem pembelajaran flipped classroom berbasis inkuiri terbimbing. Jika masing ada yang masih ada komponen yang belum cukup, maka dilakukan perbaikan pada prototipe I sehingga dihasilkan prototipe II.

Prototipe II yang merupakan hasil perbaikan dari perbaikan prototipe I dilakukan evaluasi formatif berupa uji coba satu satu (one-to-one evaluation) dan penilaian ahli (expert review) sehingga dihasilkan prototipe III. Uji coba satu-satu dilakukan pada tiga orang peserta didik yang telah menggunakan sistem pembelajaran flipped classroom berbasis inkuiri terbimbing pada materi Hidrolisis Garam (prototipe II) melalui wawancara. Sedangkan penilaian ahli dilakukan dengan cara penyebaran instrumen validasi kepada ahli media dan ahli materi. Ahli media terdiri atas tiga orang validator dan ahli materi terdiri atas lima orang validator. Perbaikan pada prototipe II dilakukan sesuai dengan saran dari para ahli sehingga dihasilkan prototipe III.

Pada prototipe III dilakukan evaluasi formatif berupa uji kelompok kecil (small group evalation) terhadap lima belas orang peserta didik untuk memperoleh data praktikalitas. Jumlah peserta didik yang digunakan sesuai dengan pendapat Dick et al. (2014) bahwa evaluasi kelompok kecil dapat dilakukan setidaknya pada delapan sampai dua puluh orang(Dick et al., 2014). Perbaikan yang dilakukan pada prototipe III sesuai saran yang diperoleh akan menghasilkan prototipe IV.

Tahap yang terakhir adalah assessment phase (fase penilaian). Pada tahap penilaian, prototipe IV diujicobakan pada kelompok yang lebih besar. Namun, tahap ini tidak dilakukan pada penelitian ini karena penelitian dibatasi sampai tahap pembuatan prototipe.

Setelah melakukan tahapan penelitian tersebut, diperoleh pada penelitian berupa data validitas dan data praktikalitas dari penyebaran angket validitas dan praktikalitas. Data dari angket validasi akan dianalisis dengan menggunakan rumus Aiken V. Rumusnya adalah sebagai berikut: 
1235 Pengembangan Sistem Pembelajaran Flipped Classroom Berbasis Inkuiri Terbimbing pada Materi Hidrolisis Garam - Zarnida Widia Nengsih, Mawardi Mawardi

DOI: https://doi.org/10.31004/edukatif.v3i4.546

$$
\begin{gathered}
V=\frac{\sum s}{n(c-1)} \\
s=r-I_{0}
\end{gathered}
$$

Simbol $V$ pada rumus berarti skala Aiken $\mathrm{V}$ yang akan dicari nilainya. Sedangan simbol $s$ berarti hasil pengurangan nilai yang diberikan oleh validator dengan nilai terendah pada kategori yang digunakan. Sedangkan maksud dari simbol $n, c, I_{0}$ berturut - turut adalah jumlah validator yang digunakan, nilai validitas tertinggi dan nilai validitas terendah (Pakesa \& Yusmaita, 2019).

Menurut Retnawati (2016), suatu produk dikatakan valid jika nilai $V$ besar dari 0,8. Sedangkan jika nilai $V$ nya kecil sama 0,8 dan besar dari 0,4 , maka suatu produk memiliki tingkat validitas sedang. Namun, produk dikatakan kurang valid jika nilai $V$ nya kurang sama dari 0,4(Retnawati, 2016).

Data dari angket praktikalitas akan dianalisis dengan menggunakan rumus persentase berikut ini.

$$
\text { Nilai praktikalitas }=\frac{\text { jumlah skor yang diperoleh }}{\text { jumlah skor terting } i} \times 100 \%
$$

Sistem pembelajaran dikatakan sangat praktis jika nilai persentasenya diperoleh $86 \%$ sampai $100 \%$. Jika persentasenya bernilai dari $76 \%$ sampai $85 \%$, maka sistem pembelajaran tersebut dikatakan praktis. Kemudian, apabila nilai persentasenya berada pada rentang $60 \%$ sampai $75 \%$, maka sistem pembelajaran dikatakan cukup valid. Namun, jika persentasenya kecil sama dari 54\% berarti sistem pembelajaran yang dihasilkan sangat tidak praktis (Purwanto, 2012).

\section{HASIL DAN PEMBAHASAN PENELITIAN}

Berdasarkan penelitian yang telah dilakukan dengan jenis Research and Development (R\&D) dengan tahapan model Plomp yang dibatasi sampai tahap pembuatan prototipe (development or prototyping phase) dan fase penilaian (assessment phase), dihasilkan sistem pembelajaran flipped classroom berbasis inkuiri terbimbing pada materi Hidrolisis Garam. Pada tahap pembuatan prototipe, dilakukan uji validitas dan uji praktikalitas untuk mengetahui kualitas produk yang telah dikembangkan.

Dalam tahap investigasi awal dilakukan tiga kegiatan, yaitu: analisis kebutuhan dan analisis konten, studi literatur, dan pengembangan kerangka konseptual. Kegiatan analisis kebutuhan dilakukan dengan melihat situsi dan kondisi proses pembelajaran pada mata pelajaran Kimia di sekolah. Proses pembelajaran yang biasanya dilakukan secara tatap muka diganti dengan pembelajaran secara daring (online). Hal ini sesuai dengan aturan yang dikeluarkan oleh pemerintah untuk meminimalisir penyebaran virus corona (Mendikbud, 2020). Di samping itu, adanya tuntutan dari kurikulum 2013 untuk melaksanakan pembelajaran yang berpusat pada peserta didik dan menunjang keaktifan peserta didik dalam belajar. Selain itu, penggunaan teknologi informasi dan komunikasi dalam pelaksanaan pembelajaran juga dibutuhkan untuk menyesuaikan dengan era revolusi 4.0.

Setelah analisis kebutuhan, dilakukanlah analisis konten terhadap materi Hidrolisis Garam yang diajarkan waktu semester 2 kelas XI SMA/MA. Hasil analisis kebutuhan diperoleh IPK dan tujuan pembelajaran dari Kompetensi Dasar (KD) 3.11. menganalisis kesetimbangan ion dalam larutan garam dan menghitung pH-nya.

Hasil pada tahap studi literatur adalah: (1) Pembelajaran flipped classroom merupakan bagian dari submodel blended learning, yaitu model rotasi (Watson et al., 2015) yang terbagi atas pembelajaran di luar kelas dan pembelajaran di dalam kelas (Syakdiyah et al., 2020); (2) Edmodo merupakan salah satu LMS (Learning Management System) berupa aplikasi pendidikan yang bertindak sebagai sumber belajar yang menghubungkan peserta didik dengan dengan semua orang untuk mencapai tujuan belajar; dan (3) Tahapan pembelajaran inkuiri terbimbing terdiri atas: orientasi, eksplorasi, pembentukan konsep, aplikasi, dan penutup (Hanson, 2005). 
1236 Pengembangan Sistem Pembelajaran Flipped Classroom Berbasis Inkuiri Terbimbing pada Materi Hidrolisis Garam - Zarnida Widia Nengsih, Mawardi Mawardi

DOI: https://doi.org/10.31004/edukatif.v3i4.546

Melalui analisis kebutuhan, dapat diketahui masalah yang dihadapi berupa pembelajaran dilaksanakan secara daring serta adanya tuntutan pembelajaran berpusat pada peserta didik oleh Kurikulum 2013. Sedangkan dari studi literatur, solusi yang dapat digunakan untuk mengatasi masalah tersebut adalah dikembangkannya sistem pembelajaran yang dapat diterapkan secara online dan peserta didik tetap bisa berpartisipasi aktif dalam pembelajaran. Sistem pembelajaran tersebut adalah gabungan pembelajaran flipped classroom dengan pembelajaran inkuiri terbimbing. Penggabungan strategi pembelajaran flipped classroom model lain juga pernah dilakukan oleh Béres \& Kis (2018) (Béres \& Kis, 2018). Dia menggabungkan strategi pembelajaran flipped classroom dengan metode pembelajaran kerja kelompok berbasis proyek. Melalui penelitian tersebut dapat disimpulkan bahwa terjadinya peningkatan tanggung jawab peserta didik dalam kegiatan belajar melalui penggabungan metode flipped classroom dengan kerja kelompok berbasis proyek.

Berdasarkan penelitian oleh Béres \& Kis (2018)(Béres \& Kis, 2018), peneliti ingin mengembangkan sistem pembelajaran flipped classroom berbasis inkuiri terbimbing. Pada sistem pembelajaran ini, tahapan inkuiri terbimbing dilakukan secara flipped classroom. Tahapan inkuiri terbimbing yang dilakukan secara asynchronous adalah tahap orientasi, eksplorasi dan pembentukan konsep, dan tahap aplikasi menggunakan aplikasi Edmodo. Sedangkan tahapan penutup dilakukan secara asynchronous menggunakan aplikasi Zoom Untuk lebih jelasnya, langkah-langkah pembelajaran flipped classroom berbasis inkuiri terbimbing dapat dilihat pada Gambar 1.

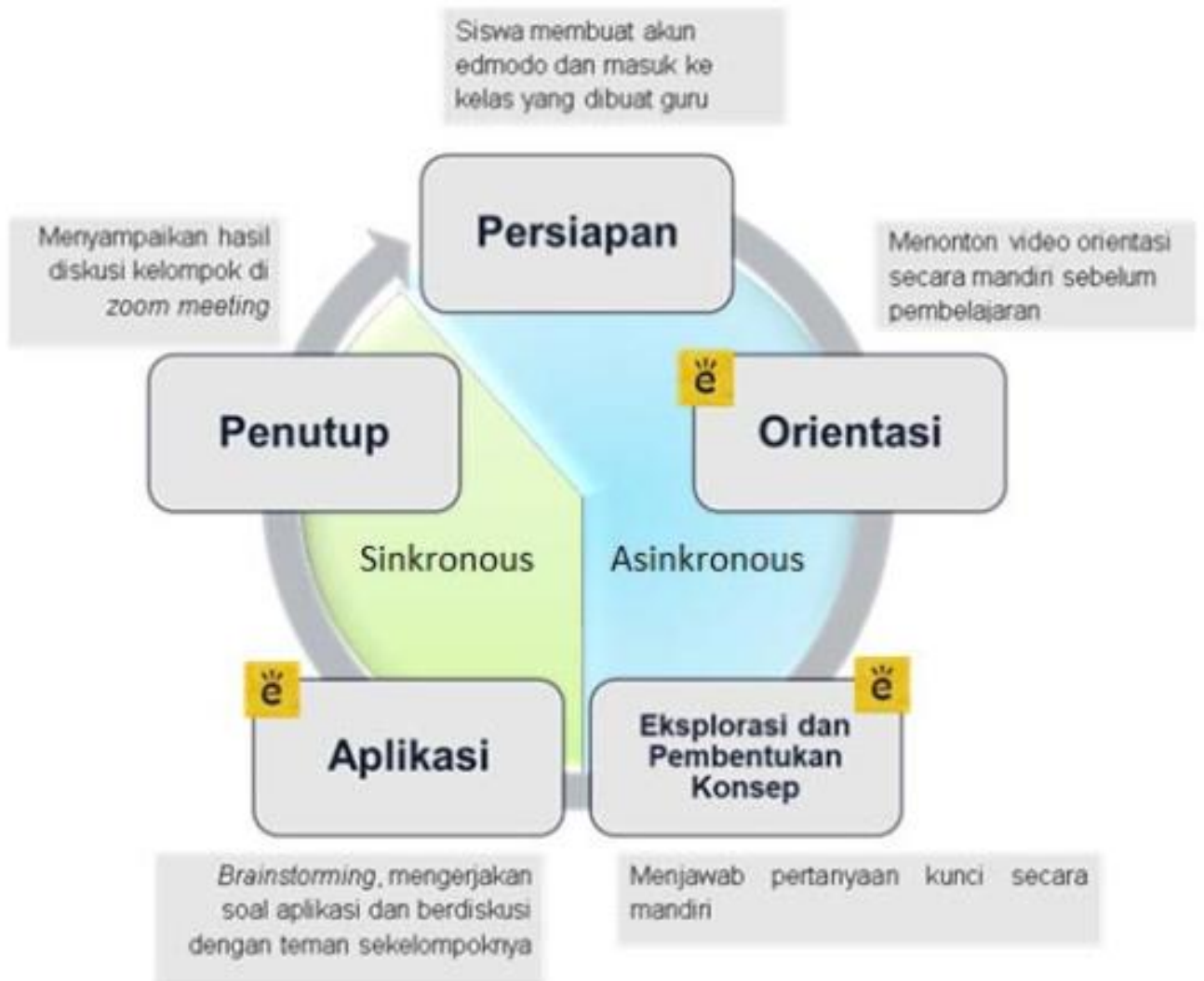

Gambar 1. Siklus Pembelajaran Flipped Classroom Berbasis Inkuiri Terbimbing(Aumi \& Mawardi, 2021)

Prototipe I yang dihasilkan berupa sistem pembelajaran flipped classroom berbasis inkuiri terbimbing yang telah dimasukkan ke dalam LMS Edmodo. Tahapan pembelajarannya yang pertama adalah tahap orientasi. Pada tahap ini, peserta didik dipersiapkan untuk belajar. Tahap ini diberikan kepada peserta didik berupa video yang telah dipersiapkan oleh guru dan diunggah ke beranda kelas pada aplikasi Edmodo. Video tersebut dapat berisi penjelasan motivasi, pengetahuan awal, ataupun tujuan pembelajaran, diberikan dalam bentuk video yang dapat berisi penjelasan motivasi, pengetahuan awal(Mawardi \& Asra, 2011), ataupun tujuan pembelajaran yang diunggah ke Edmodo. 
1237 Pengembangan Sistem Pembelajaran Flipped Classroom Berbasis Inkuiri Terbimbing pada Materi Hidrolisis Garam - Zarnida Widia Nengsih, Mawardi Mawardi

DOI: https://doi.org/10.31004/edukatif.v3i4.546

Tahapan inkuiri terbimbing kedua yaitu tahap eksplorasi dan pembentukan konsep. Pada tahap eksplorasi dan pembentukan konsep ini, peserta didik menganalisis model (gambar, tabel, dll.) untuk menemukan jawaban dari pertanyaan kunci di aplikasi Edmodo. Tujuannya adalah supaya peserta didik mampu menemukan konsep yang dipelajari. Tahapan ini diposting oleh guru pada fitur kelas kecil (small group) di Edmodo.

Tahapan inkuiri terbimbing selanjutnya adalah tahap aplikasi. Pada tahap ini, peserta didik mengerjakan latihan dengan berdiskusi bersama anggota kelompoknya. Latihan tersebut diposting oleh guru pada pada fitur kelas kecil (small group) di Edmodo. Kegiatan diskusi dapat dilakukan pada kolom komentar.

Tahapan terakhir inkuiri terbimbing adalah tahap penutup. Perwakilan dari setiap kelompok akan menyampaikan hasil kerjanya pada tahap penutup ini. Selanjutnya, guru akan mengkonfirmasi dan memberikan penguatan terhadap konsep yang telah diperoleh. Tahap penutup dilakukan menggunakan aplikasi Zoom. Link untuk bergabung ke dalam dalam meeting pada aplikasi Zoom dibagikan melalui postingan guru pada beranda kelas Edmodo. Setelah dihasilkan rancangan pertama yang disebut dengan prototipe I, maka dilakukan evaluasi formatif berupa self evaluation dengan sistem check list untuk melihat kelengkapan komponen-komponen yang harus tersedia pada sistem pembelajaran flipped classroom berbasis inkuiri terbimbing. Komponen-komponen utamanya, yaitu: (1) video orientasi, (2) model beserta pertanyaan kunci, (3) latihan, dan (4) link Zoom untuk tahap penutup. Berdasarkan hasil self evaluation, prototipe I telah memenuhi komponen-kompen yang harus tersedia pada sistem pembelajaran berbasis inkuiri terbimbing sehingga prototipe I langsung menjadi prototipe II tanpa perbaikan.

Uji coba satu satu (one-to-one evaluation) dan penilaian ahli (expert review) dilakukan pada prototipe II. Berdasarkan hasil wawancara pada uji coba satu satu terhadap tiga orang peserta didik, ternyata video orientasi yang diberikan sudah jelas dan mudah dipahami. Menurut Qurrotaini et al. (2020), penggunaan media video yang jelas dalam pembelajaran dapat membuat peserta didik lebih mudah mempelajari materi pembelajaran(Qurrotaini et al., 2020). Selain itu, penggunaan bahasanya juga sudah jelas. Hal ini dapat menghindari kesalahpahaman tujuan yang ingin disampaikan oleh guru sehingga peserta didik tidak akan kebingungan dalam melaksanakan kegiatan pembelajaran (Ningrum, 2020). Melalui penilaian oleh ahli, diperoleh data untuk mengetahui tingkat validitas sistem pembelajaran flipped classroom berbasis inkuiri terbimbing yang dikembangkan, baik itu validitas materi maupun validitas media. Hasil analisis data validasi materi dan validasi media dapat dilihat pada Tabel 1 dan Tabel 2.

Tabel 1. Hasil Analisis Angket Validasi Materi

\begin{tabular}{|c|l|c|c|}
\hline No & \multicolumn{1}{|c|}{ Aspek yang Dinilai } & V & $\begin{array}{c}\text { Kategori } \\
\text { Kevalidan }\end{array}$ \\
\hline 1 & Kelayakan isi & 0,86 & Valid \\
\hline 2 & Komponen kebahasaan & 0,86 & Valid \\
\hline 3 & Komponen penyajian & 0,88 & Valid \\
\hline 4 & Komponen kegrafikaan & 0,89 & Valid \\
\hline \multicolumn{2}{|c|}{ Rata-rata V } & 0,87 & Valid \\
\hline
\end{tabular}

Tabel 2. Hasil Analisis Angket Validasi Media

\begin{tabular}{|c|l|c|c|}
\hline No & Aspek yang Dinilai & V & $\begin{array}{c}\text { Kategori } \\
\text { Kevalidan }\end{array}$ \\
\hline 1 & Aspek tampilan & 0,85 & Valid \\
\hline 2 & Kemudahan penggunaan & 0,87 & Valid \\
\hline & Rata-rata V & 0,865 & Valid \\
\hline
\end{tabular}


1238 Pengembangan Sistem Pembelajaran Flipped Classroom Berbasis Inkuiri Terbimbing pada Materi Hidrolisis Garam - Zarnida Widia Nengsih, Mawardi Mawardi

DOI: https://doi.org/10.31004/edukatif.v3i4.546

Aspek kelayakan isi dinilai berdasarkan kesesuaian materi Hidrolisis Garam pada sistem pembelajaran flipped classroom berbasis inkuiri terbimbing dengan silabus, Kompetensi Dasar (KD), Indikator Pencapaian Kompetensi (IPK), serta tujuan pembelajaran seperti yang dikembangkan pada tahap analisis konten sebelumnya. Selain itu, kesesuaian video orientasi dan model dengan materi hidrolisis garam, kesesuaian pertanyaan kunci dengan model dalam menemukan konsep, serta kesesuaian latiahan yang diberikan juga menjadi poin-poin yang dinilai pada aspek kesesuaian isi. Berdasarkan Tabel 1, aspek kelayakan isi memperoleh nilai $\mathrm{V}=0,86$ dengan kategori valid. Kemudian, aspek komponen kebahasaan menilai penggunaan bahasa pada penyampaian informasi dan instruksi di dalam sistem pembelajaran flipped classroom berbasis inkuiri terbimbing dan kesesuai pengguaan bahasa pertanyaan kunci dengan aturan penulisan bahasa Indonesia. Berdasarkan Tabel 1, hasil analisis data untuk aspek kebahasaan dengan rumus Aiken $\mathrm{V}$ diperoleh nilai $\mathrm{V}=0,86$ dengan kategori valid.

Pada aspek komponen penyajian, dilakukan penilaian terhadap kesesuaian desain pembelajaran yang disajikan pembelajaran flipped classroom dan kesesuaian aktivitas pembelajaran dengan tahapan inkuiri terbimbing. Selain itu, penilaian juga dilakukan terhadap penyajian video orientasi, penyajian gambar/model, pertanyaan kunci, dan tahap aplikasi. Berdasarkan penilaian yang dilakukan oleh lima orang validator, diperoleh nilai $\mathrm{V}=0,88$ dengan kategori valid untuk aspek komponen penyajian. Kemudian, penilaian terhadap tata letak atau tampilan sistem pembelajaran flipped classroom berbasis inkuiri terbimbing serta kemenarikan sistem pembelajaran yang dihasilkan menjadi poin-poin pada komponen kebahasaan. Berdasarkan tabel 1 terlihat bahwa komponen kegrafikaan memiliki nilai $\mathrm{V}=0,89$ degan kategori valid.

Selain dilakukannya validasi terhadap materi, uji validasi juga dilakukan pada media yang digunakan pada sistem pembelajaran flipped classroom berbasis inkuiri terbimbing, yaitu Edmodo. Aspek-aspek yang dinilai pada validasi media ada dua, yaitu aspek tampilan dan aspek kemudahan penggunaan. Pada aspek tampilan, dilakukan penilaian terhadap tampilan fitur-fitur yang ada pada Edmodo. Sedangkan pada aspek kemudahaan penggunaan dilakukukan penilaian terhadap kesesuai fitur-fitur tersebut untuk mendukung pelaksanaan pembelajaran flipped classroom. Berdasarkan Tabel 2, aspek tampilan dan aspek kemudahan telah valid dengan nilai $\mathrm{V}$ berturut-turut adalah 0,85 dan 0,87 .

Pada prototipe III, dilakukan uji coba kelompok kecil (small group evaluation) sehingga dihasilkan prototipe IV. Pada tahap ini, sistem pembelajaran flipped classroom berbasis inkuiri terbimbing pada materi hidrolisis garam diujicobakan pada lima belas orang peserta didik. Setelah itu, peserta didik diminta untuk mengisi angket respon peserta didik sehingga diperoleh data untuk mengetahui tingkat praktikalitas dari sistem pembelajaran yang dikembangkan. Selain itu, angket repon guru juga berikan kepada tiga orang guru Kimia. Hasil analisis angket respon peserta didik dan angket respon guru dapat dilihat pada Gambar 2 dan Gambar 3. 
1239 Pengembangan Sistem Pembelajaran Flipped Classroom Berbasis Inkuiri Terbimbing pada Materi Hidrolisis Garam - Zarnida Widia Nengsih, Mawardi Mawardi

DOI: https://doi.org/10.31004/edukatif.v3i4.546

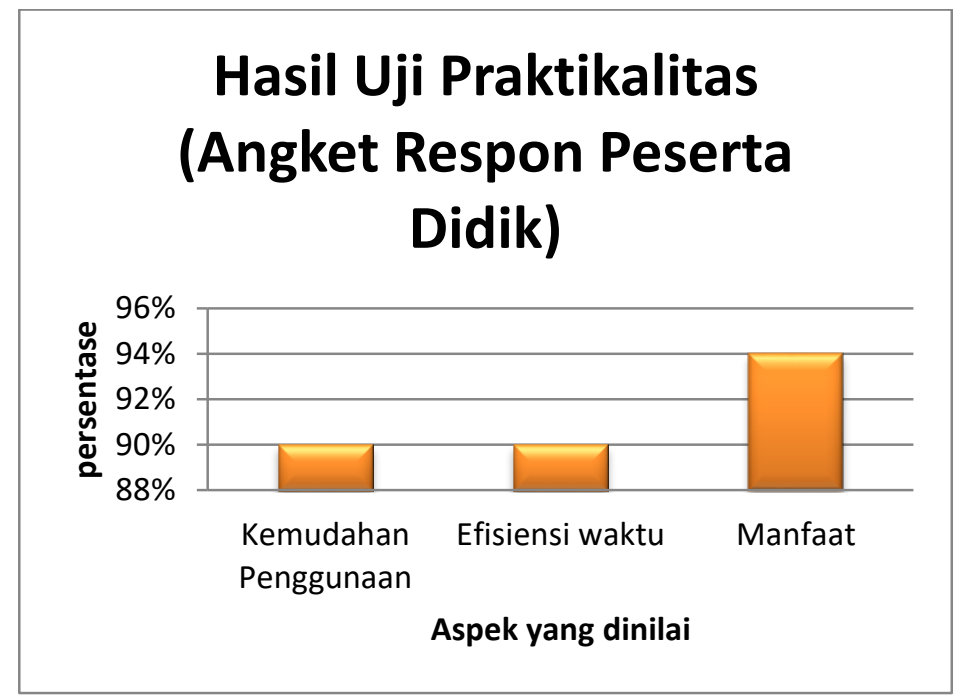

Gambar 2. Hasil Analisis Angket Respon Peserta Didik

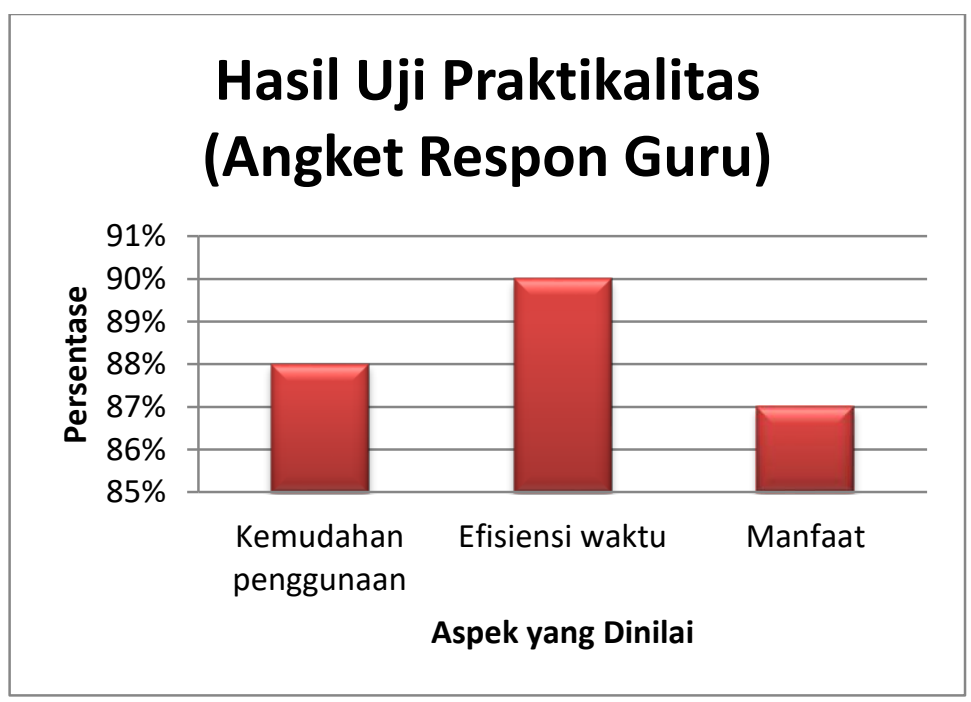

Gambar 3. Hasil Analisis Angket Respon Guru

Aspek yang dinilai pada uji praktikalitas ada tiga, yaitu aspek kemudahaan penggunaan, aspek efisiensi waktu, dan aspek manfaat. Aspek kemudahan berhubungan dengan kemudahan penggunaan sistem pembelajaran flipped classroom berbasis inkuiri terbimbing dalam pembelajaran online. Kalau aspek efisiensi waktu berhubungan dengan penggunaan waktu pembelajaran dengan sistem pembelajaran flipped classroom berbasis inkuiri terbimbing. Sedangkan aspek manfaat berhubungan manfaat yang diperoleh melalui pembelajaran dengan sistem pembelajaran flipped classroom berbasis inkuiri terbimbing.

Berdasarkan hasil analisis data validasi materi pada tabel 1, isi materi pada sistem pembelajaran flipped classroom berbasis inkuiri terbimbing telah layak diterapkan karena diperoleh nilai $\mathrm{V}=0,86$ dengan kategori valid sesuai dengan pendapat Retnawati (2016) (Retnawati, 2016). Hal ini dikarenakan materi hidrolisis garam pada sistem pembelajaran flipped classroom berbasis inkuiri terbimbing disusun sesuai dengan silabus, Kompetensi Dasar (KD), Indikator Pencapaian Kompetensi (IPK), serta tujuan pembelajaran seperti yang dikembangkan pada tahap analisis konten sebelumnya. Kesesuaian materi yang diajar menjadi salah satu faktor penentu keberhasilan peserta didik dalam belajar (Zulkifli \& Royes, 2018). Selain itu, video orientasi dan model yang disajikan telah sesuai dengan materi Hidrolisis Garam. Gabungan pertanyaan kunci dengan model dapat membantu siswa dalam menemukan konsep. Latihan yang diberikan juga dapat memantapkan konsep yang diperoleh peserta didik. Hal ini sesuai dengan penelitian yang dilakukan oleh Aumi dan Mawardi 
1240 Pengembangan Sistem Pembelajaran Flipped Classroom Berbasis Inkuiri Terbimbing pada Materi Hidrolisis Garam - Zarnida Widia Nengsih, Mawardi Mawardi

DOI: https://doi.org/10.31004/edukatif.v3i4.546

(2021) yang menyatakan bahwa peserta didik akan mampu memperoleh konsep jika gabungan model yang disediakan jelas sehingga peserta didik dapat menganalisisnya untuk menjawab pertanyaan kunci (Aumi \& Mawardi, 2021).

Pada segi komponen kebahasaan, diperoleh nila $\mathrm{V}=0,86$ dengan kategori valid. Hal ini berarti penyampaian informasi dan instruksi pada sistem pembelajaran flipped classroom berbasis inkuiri terbimbing menggunakan bahasa yang jelas dan tidak ambigu sehingga tidak menimbulkan kegandaan makna. Selain itu, pertanyaan kunci di sediakan pada Edmodo juga telah sesuai dengan aturan penulisan bahasa Indonesia yang baik. Menurut Wicaksosno (2016), penggunaan bahasa menjadi salah satu penentu keberhasilan dalam kegiatan belajar(Wicaksono, 2016).

Berdasarkan Tabel 1, komponen penyajian sistem pembelajaran flipped classroom berbasis inkuiri terbimbing memiliki nilai $\mathrm{V}=0,88$. Menurut Retnawati (2016), jika nilai $\mathrm{V}$ besar dari 0,8 maka komponen tersebut termasuk kategori valid (Retnawati, 2016). Hal ini berarti desain pembelajaran yang disajikan sesuai dengan pembelajaran flipped classroom, yaitu pembalajaran di luar kelas dan pembelajaran di dalam kelas. Selaian itu, kegiatan pembelajaran disusun sesuai dengan tahapan inkuiri terbimbing menurut pendapat Hanson (2005) (Hanson, 2005). Video orientasi juga disajikan dengan kualitas gambar dan suara yang baik. Kemudian, pertanyaan kunci juga telah disajikan dari yang sederhana sampai yang kompleks. Tahap aplikasi yang disajikan juga memungkinkan terjadinya diskusi antar kelompok sehingga peserta didik diharapkan dapat aktif dalam belajar. Hal ini sesuai dengan pendapat Mawardi \& Asra (2011) bahwa kurikulum 2013 menuntut pelaksanaan pembelajaran yang aktif(Mawardi \& Asra, 2013). Kemudian, berdasarkan Tabel 1 terlihat bahwa komponen kegrafikaan memiliki nilai $\mathrm{V}=0,89$ degan kategori valid. Hal ini menunjukkan bahwa tata letak atau tampilan sistem pembelajaran flipped classroom berbasis inkuiri terbimbing sudah teratur dan desain keseluruhan dari sistem pembelajaran tersebut sudah menarik. Namun, ada beberapa perbaikan pada rancangan sistem pembelajaran flipped classroom berbasis inkuiri terbimbing berdasarkan saran dari ahli materi untuk kesempurnaan sistem pembelajaran yang dikembangkan. Beberapa perbaikan tersebut adalah menambahkan kata-kata instruksi pada pertanyaan kunci, mengubah posisi guru pada video dari bawah ke atas, menyamakan keterangan anion dan kation pada model, serta menambahkan petunjuk pembelajaran untuk guru dan peserta didik.

Selain penilaian ahli materi, penilaian juga dilakukan oleh ahli media terhadap media yang digunakan pada pembelajaran flipped classroom berbasis inkuiri terbimbing. Berdasarkan hasil analisis data validitas media pada Tabel 2, aspek tampilan dan kemudahan penggunan sistem pembelajaran telah valid. hal ini berarti media ang diguankan, yaitu aplikasi Edmodo memiliki fitur-fitur yang dapat mendukung terlaksananya pembelajaran online secara flipped classroom berbasis inkuiri terbimbing. Fitur-fitur tersebut diantaranya adalah fitur small group untuk pembuatan kelompok belajar, fitur quiz untuk memasukkan model dan pertanyaan kunci untuk tahap eksplorasi dan pembentukan konsep di Edmodo, fitur assignment yang dapat digunakan untuk memasukkan latihan pada Edmodo, dan lain sebagainya.

Berdasarkan hasil analisis data uji praktikalitas pada Gambar 2 dan Gambar 3, aspek kemudahan penggunaan dari respon peserta didik dan respon guru diperoleh persentasenya berturut $90 \%$ dan $88 \%$. Menurut Purwanto (2012), persentasenya bernilai $86 \%$ sampai $100 \%$ termasuk kategori sangat praktis (Purwanto, 2012). Hal ini berarti langkah-langkah pembelajaran flipped classroom berbasis inkuiri terbimbing mudah dilakukan dan mudah dipahami oleh peserta didik. Pertanyaan kunci dan bahasa pada sistem pembelajaran tersebut. Namun, ada perbedaan cara pemahaman dan penganalisisan model oleh peserta didik. Sebagai contoh akan dikemukakan pada pembelajaran untuk mencapai Indeks Pencapaian Kompetensi (IPK) menganalisis konsep hidrolisis garam dengan model seperti Gambar 4. 
1241 Pengembangan Sistem Pembelajaran Flipped Classroom Berbasis Inkuiri Terbimbing pada Materi Hidrolisis Garam - Zarnida Widia Nengsih, Mawardi Mawardi

DOI: https://doi.org/10.31004/edukatif.v3i4.546

\section{Model 2}

Berikut gambar ketika 5 gram $\mathrm{NaF}$ dilarutkan ke dalam air

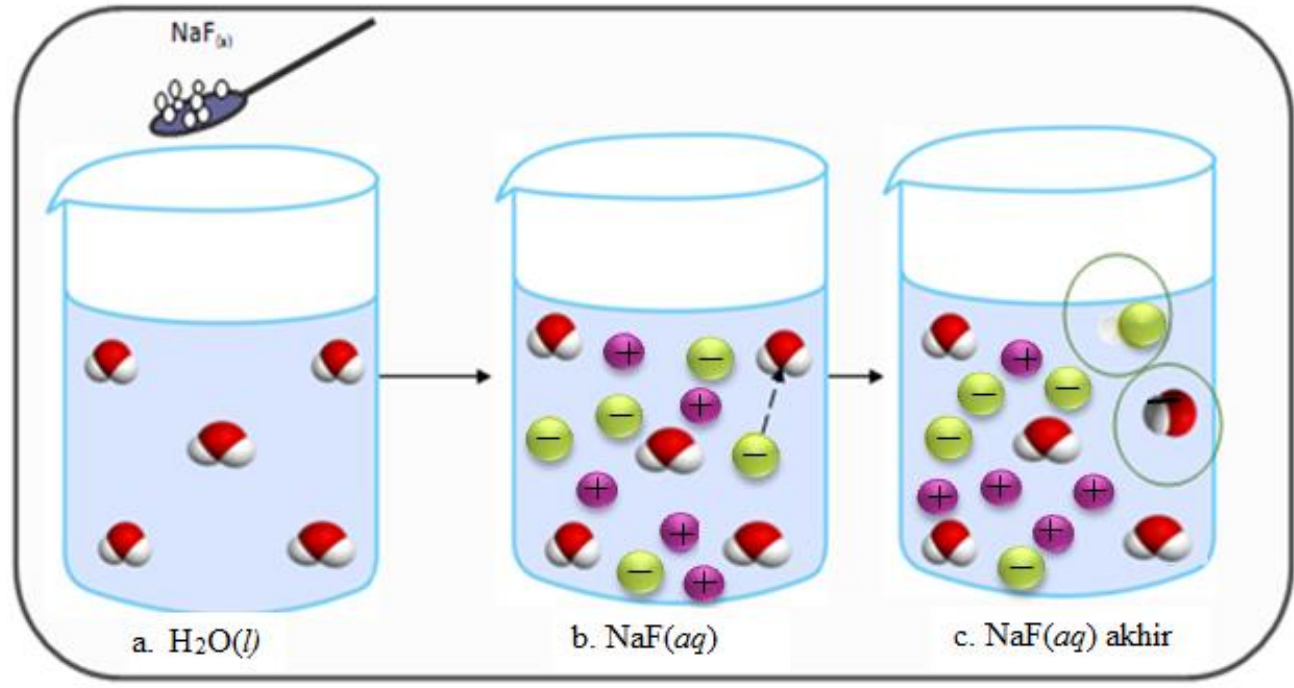

Sumber: Dimodifikasi dari wwwkkimia-science 7.com

$\begin{aligned} \text { Informasi: } & & & \\ & =\mathrm{H}_{3} \mathrm{O}^{+} & & =\mathrm{Na}^{+} \\ & =\mathrm{H}_{2} \mathrm{O} & & =\mathrm{F}^{-} \\ & =\mathrm{OH}^{-} & & =\mathrm{HF}\end{aligned}$

Gambar 4. Contoh Tampilan Model pada Materi Hidrolisis Garam

Tiga orang peserta didik dengan nilai tertinggi (PD1), peserta didik dengan nilai sedang (PD2), dan peserta didik dengan nilai nilai terendah (PD3) diwawancarai untuk mengetahui cara pemahamannya terhadap model seperti Gambar 4. PD1 menganalisis model tersebut dengan melihat ion $\mathrm{F}^{-}$berdekatan dengan molekul $\mathrm{H}_{2} \mathrm{O}$ seperti pada bagian b di gambar 4 yang ditandai dengan tanda panah. Kemudian, ion $\mathrm{F}^{-}$tadi berikatan dengan $\mathrm{H}^{+}$yang lepas dari molekul air sehingga yang terbentuk adalah $\mathrm{HF}$ dan $\mathrm{OH}^{-}$seperti yang dilingkari pada gambar bagian c di Gambar 4.

Berdasarkan hasil wawancara dengan PD2 diketahui bahwa dia menganalisis model dengan melihat jumlah ion-ion dan molekul pada setiap gelas kimia yang tersedia di Gambar 4. Pada gelas b, terdapat lima molekul air, lima ion $\mathrm{Na}^{+}$, lima ion $\mathrm{F}^{-}$. Namun, pada gelas $\mathrm{c}$ jumlah moleku $\mathrm{H}_{2} \mathrm{O}$ dan ion $\mathrm{F}^{-}$masing-masing berkurang satu sedangkan jumlah ion $\mathrm{Na}^{+}$tidak berubah. Selain itu, PD2 juga melihat ada ion $\mathrm{OH}^{-}$dan unit $\mathrm{HF}$ pada gelas c yang sebelumnya tidak ada pada gelas b. Hal ini menandakan ada terjadinya pemecahna molekul dan berikatannya ion di dalam larutan tersebut. Namun, PD2 memiliki kesalahan dalam penulisan muatan ionion pada jawaban pertanyaan kunci di Edmodo. Selanjutnya, PD3 mengalami kesalahan dalam menjawab pertanyaan kunci yang menanyakan hasil ionisasi garam $\mathrm{NaCl}$ di dalam air. Dia menjawab bahwa $\mathrm{NaCl}$ terion menjadi $\mathrm{Na}^{+}$dan $\mathrm{F}^{-}$. berdasarkan tanya jawab dengan PD3 ini, didapatkan informasi bahwa peserta didik ini tidak terlalu serius dalam menganalisis model pada Gambar 4. Dia hanya melihat sepintas saja tanpa melihat keterangan pada model dengan jelas. Hal ini mengakibatkan kesalahan akibat kecerobohan dalam menganalisis model dan menjawab pertanyaan kunci.

Berdasarkan deskripsi hasil wawancara terhadap ketiga peserta didik, dapat diketahui setiap peserta didik memiliki caranya masing-masing dalam menganalisis suatu model. Menurut Azis \& Sardin (2016), perbedaan cara peserta didik dalam menganalisis sesuai disebabkan karena adanya perbedaan motivasinya untuk belajar (Azis \& Sardin, 2016). Perbedaan sikap dan minat juga mempengaruhi kemampuan dalam menganalisis. Cara belajar atau gaya belajar seorang peserta didik juga dapat berpengaruh terhadap kemampuannya dalam menganalisis. 
1242 Pengembangan Sistem Pembelajaran Flipped Classroom Berbasis Inkuiri Terbimbing pada Materi Hidrolisis Garam - Zarnida Widia Nengsih, Mawardi Mawardi

DOI: https://doi.org/10.31004/edukatif.v3i4.546

Untuk aspek efesiensi waktu, nilai persentase dari peserta didik dan guru beruturut-turut pada Gambar 2 dan 3 adalah 90\% dan 90\% dengan kategori sangat praktis. Hal ini menunjukkan bahwa sistem pembelajaran flipped classroom berbasis inkuiri terbimbing pada materi hidrolisis garam sangat efisien dari segi waktu dikarenakan waktu pembelajarannya yang fleksibel (Brown, 2016). Sedangkan dari segi manfaat, pesertase dari peserta didik adalah 94\% dan $87 \%$ dari guru dengan kategori sangat praktis. Hal ini berarti sistem pembelajaran flipped classroom berbasis inkuiri terbimbing dapat membantu peserta didik dalam memahami materi Hidrolisis Garam. Selain itu, minat dan aktivitas peserta didik dalam belajar juga meningkat dengan menggunakan sistem pembelajaran ini.

Walaupun hasil analisis data praktikalitas secara keseluruhan termasuk kategori sangat praktis, tetapi masih terdapat beberapa kendala dalam pelaksanaan penelitian. Kendala tersebut berupa kekuatan signal internet yang berbeda-beda di berbagai tempat tinggal peserta didik. Hal ini mengakibatkan pelaksanaan tahap penutup dengan dengan aplikasi Zoom tidak berjalan dengan lancar sesuai dengan harapan. Kualitas signal yang buruk menjadi salah satu kendala dalam pelaksanaan pembelajaran daring. Hal ini sesuai dengan hasil penelitian oleh (Khoirunnisa, 2020) yang menyatakan bahwa kualitas signal yang buruk di pedesaan menjadi salah satu kendala dalam pelaksanaan pembelajaran daring atau pembelajaran online. Melalui penelitian ini, guru diharapkan dapat mamantau kesulitan peserta didik selama pelaksanaan pembelajaran sehingga dapat dicarikan solusi demi kelancaran pelaksanaan pembelajaran. Penelitian yang dibatasi sampai tahap uji validitas dan uji praktikalitas ini dapat menjadi pedoman pelaksanaan penelitian selanjutnya dalam menguji efektivitas sistem pembelajaran flipped classroom berbasis inkuiri terbimbing sehingga ketiga kualitas dari sistem pembelajaran ini dapat diketahui.

\section{KESIMPULAN}

Berdasarkan hasil penelitian dalam pengembangan sistem pembelajaran flipped classroom berbasis inkuiri terbimbing pada materi hidrolisis garam menggunakan model Plomp yang dibatasi sampai tahap development or prototyping phase dan tahap evaluasi formatif dibatasi sampai tahap small groups evaluation diperoleh hasil bahwa sistem pembelajaran yang dikembangkan sudah valid dengan nilai $\mathrm{V}$ rata-rata $=0,87$ dari validator ahli materi dan nilai $\mathrm{V}$ rata-rata $=0,865$ dari validator ahli media, sedangkan tingkat praktikalitasnya termasuk kategori sangat praktis dengan rata-rata persentase dari peserta didik $=92 \%$ dan rata-rata persentase dari guru $=88 \%$.

\section{DAFTAR PUSTAKA}

Aumi, V., \& Mawardi, M. (2021). Validity And Practicity Of Flipped Guided Inquiry Based Learning ( FGIL ) Model In Chemical Kinetics For Year 1 Students. International Journal of Progressive Sciences and Technologies (IJPSAT), 26(2), 142-147.

Azis, A., \& Sardin, S. (2016). Pengaruh Motivasi, Sikap, Minat, dan Gaya Belajar Statistik Mahasiswa Terhadap Kemampuan Menganalisis Persoalan Penelitian. Jurnal Akademik Pendidikan Matematika. https://doi.org/10.31219/osf.io/2xkwu

Béres, I., \& Kis, M. (2018). Flipped Classroom Method Combined with Project Based Group Work. Advances in Intelligent Systems and Computing, 715(January), 553-562. https://doi.org/10.1007/978-3-319-732107_65

Brown, B. A. (2016). Understanding the Flipped Classroom: Types, Uses and Reactions to a Modern and Evolving Pedagogy. Culminating Projects in Teacher Development, 12, 27. http://repository.stcloudstate.edu/cgi/viewcontent.cgi?article=1010\&context=ed_etds

Dick, W., Carey, L., \& Carey, J. O. (2014). Pearson New International Edition The Systematic Design of 
1243 Pengembangan Sistem Pembelajaran Flipped Classroom Berbasis Inkuiri Terbimbing pada Materi Hidrolisis Garam - Zarnida Widia Nengsih, Mawardi Mawardi

DOI: https://doi.org/10.31004/edukatif.v3i4.546

\section{Instruction.}

Fautch, J. M. (2013). The flipped classroom for teaching organic chemistry in small classes: is it effective? Chemistry Education Research and Practice, 16, 179-186. https://doi.org/10.1039/x0xx00000x

Fauzy, A., \& Nurfauziah, P. (2021). Kesulitan Pembelajaran Daring Matematika Pada Masa Pandemi COVID-19 di SMP Muslimin Cililin. Jurnal Cendekia : Jurnal Pendidikan Matematika, 5(1), 551-561. https://doi.org/10.31004/cendekia.v5i1.514

Fitriani, Y. (2020). Analisa Pemanfaatan Learning Management System (LMS) Sebagai Media Pembelajaran Online Selama Pandemi COVID-19. Journal of Information System, Informatics and Computing. https://doi.org/10.52362/jisicom.v4i2.312

Goedhart, N. S., Blignaut-van Westrhenen, N., Moser, C., \& Zweekhorst, M. B. M. (2019). The flipped classroom: supporting a diverse group of students in their learning. Learning Environments Research. https://doi.org/10.1007/s10984-019-09281-2

Hanson, D. M. (2005). Designing Process-Oriented Guided-Inquiry Activities. Faculty Guidebook - A Comprehensive Tool for Improving Faculty Performance, 1-6.

He, F., Deng, Y., \& Li, W. (2020). Coronavirus disease 2019: What we know? Journal of Medical Virology, 92(7), 719-725. https://doi.org/10.1002/jmv.25766

Jung, H., \& Brady, C. (2020). Maintaining rich dialogic interactions in the transition to synchronous online learning. Information and Learning Science. https://doi.org/10.1108/ILS-04-2020-0096

Kartika, M., Erik Aditya Ismaya, \& Muhammad Noor Ahsin. (2021). Analisis Pembelajaran Daring di SD 2 Tenggeles Mejobo Kudus pada Masa Pandemi Covid-19. Lectura: Jurnal Pendidikan. https://doi.org/10.31849/lectura.v12i1.5906

Khoirunnisa. (2020). Pembelajaran Online Pada Masa Pandemi Covid19 Sebagai Strategi Pembelajaran dan Capaian Hasil Belajar Pada Siswa Kelas III B MI Al-Ittihaad Citrosono Kecamatan Grabag Kabupaten Magelang Tahun Pelajaran 2019/2020 [institut agama islam negeri salatiga]. In institut agama islam negeri salatiga (Vol. 21, Nomor 1). http://e-repository.perpus.iainsalatiga.ac.id/9572/1/SKRIPSI KHOIRUNNISSA 23040160133 PGMI.pdf

Kohnke, L., \& Moorhouse, B. L. (2020). Facilitating Synchronous Online Language Learning through Zoom. In RELC Journal. https://doi.org/10.1177/0033688220937235

Mawardi, \& Asra. (2013). Inkuiri Terbimbing sebagai Salah Satu Strategi Pembelajaran Kimia untuk Memenuhi Tuntutan Kurikulum 2013. Prosiding Seminar Nasional Pembelajaran Fisika, 522-528.

Mawardi, \& Asra. (2011). Inovasi dalam Pembelajaran Kimia, Suatu Tinajauan Teoritis. Prosiding Seminar Nasional Kimia dan Pendidikan Kimia, 244-260.

Mendikbud. (2020). Surat Edaran Nomor 4 Tahun 2020 Tentang Pelaksanaan Kebijakan Pendidikan dalam Masa Darurat Penyebaran Coronavirus Disease (Covid-19).

Mirlanda, E. P., Nindiasari, H., \& Syamsuri, S. (2019). Pengaruh Pembelajaran Flipped Classroom Terhadap Kemandirian Belajar Siswa Ditinjau Dari Gaya Kognitif Siswa. Symmetry: Pasundan Journal of Research in Mathematics Learning and Education, 4, 38-49. https://doi.org/10.23969/symmetry.v4i1.1638

Ningrum, V. (2020). Penggunaan Kata Baku dan Tidak Baku Di Kalangan Mahasiswa Universitas Pembangunan Nasional "Veteran" Yogyakarta. Jurnal Skripta. https://doi.org/10.31316/skripta.v5i2.398

Pakesa, C. M., \& Yusmaita, E. (2019). Perancangan Assesmen Literasi Kimia Pada Materi Laju Reaksi Kelas XI SMA/MA. Edukimia, 1(3), 84-89. https://doi.org/10.24036/ekj.v1.i3.a61

Plomp. (2013). Educational Design Research Educational Design Research. Educational Design Research, 1206. http://www.eric.ed.gov/ERICWebPortal/recordDetail?accno=EJ815766

Purnawarman, P., Susilawati, \& Sundayana, W. (2016). The use of Edmodo in teaching writing in a blended 
1244 Pengembangan Sistem Pembelajaran Flipped Classroom Berbasis Inkuiri Terbimbing pada Materi Hidrolisis Garam - Zarnida Widia Nengsih, Mawardi Mawardi

DOI: https://doi.org/10.31004/edukatif.v3i4.546

learning setting. Indonesian Journal of Applied Linguistics. https://doi.org/10.17509/ijal.v5i2.1348

Purwanto, N. (2012). Prinsip-Prinsip dan Teknik Evaluasi Pengajaran. PT Remaja Rosdakarya.

Qurrotaini, L., Sari, T. W., \& Sundi, V. H. (2020). Efektivitas Penggunaan Media Video Berbasis Powtoon dalam Pembelajaran Daring. Prosiding Seminar Nasional Penelitian LPPM UMJ.

Retnawati, H. (2016). Analisis Kuantitatif Instrumen Penelitian: Panduan Penelitian, Mahasiswa, dan Psikometrian (pertama). Parama Publishin.

Simamora, R. M. (2020). The Challenges of Online Learning during the COVID-19 Pandemic: An Essay Analysis of Performing Arts Education Students. Studies in Learning and Teaching. https://doi.org/10.46627/silet.v1i2.38

Syakdiyah, H., Wibawa, B., \& Syahrial, Z. (2020). Flipped Classroom Learning Innovation as an Attempt to Strengthen Competence and Competitiveness of Students in the 4.0 Industrial Revolution Era. Formatif: Jurnal Ilmiah Pendidikan MIPA, 9(4), 267-280. https://doi.org/10.30998/formatif.v9i4.2929

Waer, W. P., \& Mawardi, M. (2021). EDUKATIF : JURNAL ILMU PENDIDIKAN Integrasi Model Inkuiri Terbimbing Dan Pendekatan Flipped Classroom Pada Pembelajaran Materi Sifat Koligatif Larutan Untuk Siswa Kelas XII SMA / MA. 3(3), 1029-1037.

Wahyuni, S., Gusti Made Sanjaya, I., Erman, \& Jatmiko, B. (2019). Edmodo-based blended learning model as an alternative of science learning to motivate and improve junior high school students' scientific critical thinking skills. International Journal of Emerging Technologies in Learning. https://doi.org/10.3991/ijet.v14i07.9980

Watson, J., Powell, A., Staley, P., Patrick, S., Horn, M., Fetzer, L., Hibbard, L., Oglesby, J., Verma, S., Education, M., C, T. O. C.-I. N. B., Kuehn, B. L., Ed, D., Archibald, D., Barbour, M. K., Leary, H., Wilson, E. V., \& Ostashewski, N. (2015). Teacher education and K-12 online learning. iNACOL, The International Association for $K-12$ Online Learning, July, 1-20. http://files.eric.ed.gov/fulltext/ED560788.pdf

Wicaksono, L. (2016). Bahasa Dalam Komunikasi Pembelajaran. Jurnal Pembelajaran Prospektif, 1(2), 9-19. http://jurnal.untan.ac.id/index.php/lp3m\%0Ahttp://jurnal.untan.ac.id/index.php/lp3m/article/download/1 $9211 / 16053$

Widyasari, L. A., \& Rafsanjani, M. A. (2021). EDUKATIF: JURNAL ILMU PENDIDIKAN Apakah Penerapan Blanded Learning Dapat Meningkatkan Motivasi dan Hasil Belajar Siswa dalam Pembelajaran Jarak Jauh? 3(3), 854-864.

Yuliati, Y., \& Saputra, D. S. (2019). Pembelajaran Sains Di Era Revolusi Industri 4.0. Jurnal Cakrawala Pendas, 5(2). https://doi.org/10.31949/jcp.v5i2.1389

Zulkifli, Z., \& Royes, N. (2018). Profesionalisme Guru Dalam Mengembangkan Materi Ajar Bahasa Arab di MIN 1 Palembang. JIP: Jurnal Ilmiah PGMI. https://doi.org/10.19109/jip.v3i2.1646 